https://helda.helsinki.fi

\title{
Implementing virtual collaborative inquiry practises in a middle-school context
}

\section{Lakkala, Minna}

2007

Lakkala , M , llomäki , L \& Palonen , T 2007 , ' Implementing virtual collaborative inquiry practises in a middle-school context ' , Behaviour \& Information Technology, vol. 26 , no. 1 , pp. 37-53 . https://doi.org/10.1080/01449290600811529

http://hdl.handle.net/10138/27971

https://doi.org/10.1080/01449290600811529

submittedVersion

Downloaded from Helda, University of Helsinki institutional repository.

This is an electronic reprint of the original article.

This reprint may differ from the original in pagination and typographic detail.

Please cite the original version. 
Lakkala, M., Ilomäki, L., \& Palonen, T. (2007). Implementing virtual, collaborative inquiry practices in a middle school context. Behaviour \& Information Technology, 26(1), 37-53.

This is a preprint of an article whose final and definitive form has been published in the Behaviour and Information Technology ( 0 [2007] [copyright Taylor \& Francis]; Behaviour and Information Technology is available online at: http://journalsonline.tandf.co.ukd.

\title{
Implementing virtual collaborative inquiry practises in a middle school context
}

\author{
MINNA LAKKALA*†, LIISA ILOMÄKI $\dagger$ and TUIRE PALONEN \\ $\dagger$ Centre for Research on Networked Learning and Knowledge Building, Department of \\ Psychology, P.O. Box 9, 00014 University of Helsinki, Finland \\ $\$$ Faculty of Education, University of Turku, Assistenkinkatu 5, 20014 TURKU, Finland \\ C*Corresponding author. Email: Minna.Lakkala@ helsinki.fi
}

The aim of the study was to investigate the challenges that relate to the implementation of virtual inquiry practises in middle school. The case was a school course in which a group of Finnish students $(\mathrm{N}=14)$ and teachers $(\mathrm{N}=7)$ completed group inquiries through virtual collaboration, using a Web-based learning environment. The task was to accomplish a cross-disciplinary inquiry into cultural issues. The students worked mainly at home and took much responsibility for their course achievements. The investigators analysed the pedagogical design of the course and the content of the participants' interaction patterns in the Web-based environment, using qualitative content analysis and social network analysis. The findings suggest that the students succeeded in producing distinctive cultural products, and both the students and the teachers adopted novel roles during the inquiry. The Web-based learning environment was used more as a coordination tool for organizing the collaborative work than as a forum for epistemic inquiry. The tension between the school curriculum and the inquiry practises was manifest in the participants' discussions of the assessment criteria of the course.

Keywords: Progressive inquiry learning; Virtual learning; Collaborative knowledge building; Pedagogical design; Pedagogical innovation; Middle school

\section{Introduction}

In recent years, the new possibilities of modern Web-based technologies have generated expectations of profound changes in education. According to these expectations, technology can transform school learning, e.g. by providing easy access to information and 
real-world problems, new means for communication and collaboration, and tools for developing higher-order thinking and knowledge management skills (Bransford et al. 2000, Roschelle et al. 2000, Hofer 2004). These expectations stem from beliefs that the future knowledge society requires competencies that develop only through participation in the collaborative practises of working with knowledge and solving authentic problems of understanding (Scardamalia and Bereiter 1999, Hakkarainen et al. 2004).

According to several studies (Dexter et al. 1999, Lim and Barnes 2002, Windschitl and Sahl 2002), a technology, as such, does not automatically change educational practises; teachers' deliberate effort to develop the learning culture is also needed. Previous experiences (Smeets and Mooij 2001, Salomon 2002) have shown that modern technology is often assimilated into the prevailing educational philosophy and practises, and the affordances of technology are not fully exploited to change the quality or nature of education.

Recent studies, however, have also reported promising examples of emerging, innovative ways of using information and communication technology (ICT) to change teaching and learning practises in schools around the world. Based on the examination of 174 case studies, Kozma (2003) listed the following features that characterise innovative classroom practises in which technology has been used to change pedagogy: the usage of ICT is integrated into the curriculum; students work collaboratively and use ICT to search for information, publish results and create products; and teachers change their role from delivering knowledge to organizing, guiding and assessing students' learning processes. Kozma concluded that "when students also use technology to conduct research projects, analyse data, solve problems, design products, and assess their own work, students are more likely to develop new ICT, problem solving, information management, collaboration, and communication skills" (p. 13). In order to better understand the possibilities and challenges of transforming school education with technology, such cases of advanced and innovative pedagogical practises should be the object of detailed scientific examination.

The present study examines a case in which teachers seriously strove to develop their educational practise with technology, embedded in a meaningful pedagogy and new ways of working with students. The pedagogical setting had several features that may be described as innovative (Kozma 2003), which was the reason why it was chosen for investigation. Several teachers participated in the planning and implementation of the investigated course, and they had an ambitious goal to get middle school students acquainted with the practises of inquiry learning and distance working mediated by Webbased technology.

\section{Progressive inquiry learning}

The pedagogical approach that the teachers applied in the investigated case was progressive inquiry learning (Hakkarainen 2003, Muukkonen et al. 2005), a term meant to characterize a sustained process of advancing and building knowledge characteristic of scientific inquiry, in this case, with the support of Web-based technology. The aim is not merely to achieve content mastery; a parallel emphasis is on skills in solving problems and constructing new knowledge, which resembles the practises of expertise and teamwork.

Bereiter and Scardamalia (1993, Scardamalia and Bereiter 1999) proposed that with the support of appropriate technologies, schools should become knowledge-building organizations, in which students and teachers participate in the construction of collective knowledge, and the primary goal of activity is not individual learning, but solving of 
authentic knowledge problems. The progressive inquiry approach shares with the knowledge-building approach an assumption that inquiry is seen as a process mediated by shared knowledge objects, such as questions, explanations, plans, and ideas (Bereiter and Scardamalia 1993, Paavola et al. 2002). Also in the theoretical background for the progressive inquiry model is the interrogative model of Hintikka (1999), which emphasises the important role of explanation-seeking questions in the processes of creating knowledge.

The progressive inquiry model concretises the collaborative knowledge-creation process by specifying some essential elements for epistemological advancement (Hakkarainen et al. 2004). The starting point of a progressive inquiry process is the creation of the context for inquiry by presenting a multidisciplinary approach to theoretical or reallife phenomena. The students are guided to form their own questions about the phenomena and create their intuitive working theories as explanations to answer the questions. These stages are undertaken before using authoritative information sources, to challenge the students' own thinking. The learning community acquires new information by exploiting various information sources after having together evaluated the produced ideas and explanations. The process will be repeated gradually with deepening cycles of formulating subordinate study questions and more accurate theories and knowledge products. The model is not meant to be followed rigidly, but it offers conceptual tools to discuss, organize and make visible the strategies and activities in the inquiry practise.

Essential for the advancement of a progressive inquiry process is that all knowledge objects and the phases of the process are shared within the whole learning community. Web-based technology, when properly designed, supports the progressive inquiry process by offering a virtual space for collaboratively sharing and elaborating knowledge objects, offering a basis for multiple perspectives and idea development, or providing external representations for ideas that can be referenced in collaborative discourse (Muukkonen et al. 2005, Suthers and Hundhausen 2003).

The progressive inquiry model is applied, tested and developed at many schools and universities in Finland (see Lipponen et al. 2002, Lahti et al. 2003, Veermans and Järvelä 2004, Muukkonen et al. 2005). Our recent studies (Lakkala, Lallimo et al. 2005, Lakkala, Muukkonen et al. 2005), especially, have addressed the following crucial issue: if we educators want to understand the challenges and problems in implementing progressive inquiry pedagogy in authentic educational settings, it is important to take into account the overall organisation of activities and social practises, in addition to the participants' epistemic activity during the process.

\section{Virtual collaboration}

In addition to the progressive inquiry approach, another special feature in the investigated case was the organization of the course partly as a distance learning setting: the students worked mainly off the school premises and communicated with each other, and with teachers, from home through a Web-based learning environment in addition to face-to-face meetings. In this article, we use the term virtual collaboration, meaning that the participants, while working, are physically and temporally dispersed, and the interaction between them is mediated by technology (Watson-Manheim et al. 2002). The introduction of Web-based technology in educational contexts raises the possibility of extending the collaborative learning activities beyond the school walls (Ligorio et al. 2005). Usually the studies of technology-enhanced inquiry learning at middle school level come from face-toface classroom situations (Lamon et al. 1996, Salovaara and Järvelä 2003), whereas virtual 
collaboration settings have been studied mainly in university-level education (Guzdial and Turns 2000, Schrire 2004, Muukkonen et al. 2005).

Wegerif (1998) stated that a sense of community appears to be a necessary precondition for collaborative learning to succeed. Even in conventional teacher-led classrooms students have social communication that supports academic content learning, although it is often regarded as 'off-task' behaviour (Granstrom 1996). In the study of Hogan et al. (1999) that investigated the content of $8^{\text {th }}$ grade students' face-to-face group discussions in a problem-solving task, one fourth of the group communication was about the logistical or concrete aspects of the task, and about $10 \%$ was regarded as off-task conversation.

If the participants are collaborating virtually, the challenges of organizing the learning community can be compared with the challenges of building virtual communities in general (Barab, 2003). Elements that characterise successful virtual communities are, e.g. shared goals and resources, active participation and reciprocal interaction, sense of belonging, trust in others, and the shared context of social conventions (Schuler 1996, Preece 2000). The features and affordances of the Web-based tool used for collaborative activity have, naturally, important effects on the realisation of virtual collaboration (Kirschner et al. 2004). In the investigated course, the students and teachers used a Webbased learning environment where the main collaborative tool was a quite typical, threaded discussion forum. The same kinds of forums are widely employed in learning situations (Guzdial and Turns 2000, Schrire 2004) because they are easy to use and apply, but they do not include any special tools or support for virtual inquiry, such as awareness tools or builtin cognitive scaffolds.

\section{The purpose of the study}

As Kozma (2003) stated, the positive impact of technology depends on how teachers implement technology in their pedagogical practise. Another important variable in success is the role of the institutional practises and structures of the school system in the implementation of new pedagogies (Hannafin and Land 1997, Dexter et al. 1999, Roschelle et al. 2000). Engeström et al. (2002) in their study of school change proposed that there are deep structural constraints on developing the school: Socio-spatial structure of the school work (separate classrooms, teachers working alone, the isolation of the school from the environment), temporal structure (discrete and short lessons, test and grading phases), and motivational and ethical structure (grading as the main motivational method). Bielaczyc (2001) stated that the central challenge in implementing knowledge-building pedagogy in schools lies in creating the appropriate social infrastructure around the technology implementation, such as classroom culture and norms established, classroom practises and online activities in the process, and the use of the technological environment.

Agreeing with Candela et al. (2004), we believe that in order to understand the challenges, obstacles and successes that teachers face in implementing modern technology and related pedagogical innovations in classrooms, detailed analysis of interaction processes should be undertaken within the larger structures of activities and lessons, and within the institutional and social context. The purpose of the present study is to investigate the challenges that relate to the implementation of virtual, collaborative inquiry practises in a Finnish middle-school teaching group. Based on the above review, the research questions are the following: 
1) How did the original goal of progressive inquiry pedagogy become actualised in the investigated course?

2) What was the role of the Web-based learning environment in the inquiry process, and what kind of interaction patterns emerged in the participants' virtual collaboration?

3) How did the pedagogical approach fit with the curriculum and institutional practises of the middle school, and what were the effects, if any, of such fit or lack of it?

\section{Research methods}

\subsection{The context of the study}

The evaluated course was organized in a regular middle school in the city of Helsinki. The school has a long tradition of participating in school development projects and collaborating with educational researchers. It has a reputation of an experimental school: E.g. it is the only middle school in the city of Helsinki with non-graded instructional groupings; the teachers regularly take part in pedagogical development work promoted by the principal, and some teachers participate actively in ICT projects (Ilomäki et al. 2004).

The design of the 'Culture course' was first created during an educational technology project examining the usage of portable computers; participation in the project helped the school to increase its ICT resources, among them teacher training (Sinko and Lehtinen 1999). By conducting the Culture course, the teachers of the school wanted to create a pedagogical practise that would give students a special experience before completing their compulsory education; the course has now been established as a permanent practise that is repeated every spring.

At the time of the course, the school participated in the Educational technology project of the City of Helsinki (see Ilomäki and Lakkala 2003). One aim of the technology project was to support schools in implementing Web-based technologies and virtual learning practises in their everyday teaching, which also related to the national goals of advancing virtual learning on all levels in Finnish schooling (Ministry of Education 1999). In the evaluated course, the teachers' intention was deliberately to surpass the limits of classrooms, subject domains and short-time lessons, but the teachers still acted in a conventional school context with no extra resources or changes in the official curriculum.

\subsection{Setting and participants}

The Culture course was organized under a very wide multidisciplinary theme of cultural issues, and it integrated students' work in several subject domains and school courses. The setting was also atypical in that several teachers from various subject domains took part in each group inquiry, jointly carrying out the pedagogical planning and the guidance and assessment of students. The teachers defined the following goals for the Culture course: to deepen the students' conception of culture, to give them an opportunity to experience distance learning and to introduce the students and the teachers to the progressive inquiry approach.

The progressive inquiry model was new to most of the teachers, so they were in novice roles themselves although the initiative to carry out such a course came from them. When the teachers introduced the progressive inquiry approach to the students, they explained it to be question-driven inquiry, which is structured in certain phases, and which emphasises students' own planning and self-regulated work, sharing of knowledge, and 
mutual commenting and feedback. The students were encouraged to produce an innovative cultural product as a final piece of work of the course, not just a traditional project report. The students decided the actual topic of their inquiry among themselves. The final products could take several forms: for example, as a research report, a slide show, a radio play, a wall newspaper, or an artefact exhibition.

The actual course period lasted seven weeks, from February to April, but the whole process started two months beforehand with some preliminary meetings. The students worked mainly off the school premises during the course. There were seven common meetings at school, otherwise the students communicated through the Web-based learning environment from home or arranged face-to-face meetings with their small group members and the guiding teachers. The final pieces of work, in particular, were constructed mainly in face-to-face group meetings that the students themselves voluntarily arranged, although the teachers encouraged the students to use the Web-based learning environment for knowledge sharing and communication.

The technology used in the course was a Web-based learning environment called Virtual Web School (VWS), designed by the Media Centre of the Helsinki City Department of Education. The main tool for organizing the participants' virtual inquiry was a typical threaded discussion forum. The learning environment also included a chat tool and a textbased portfolio for students' private products, but they were not in active use during the course. It was not possible, for instance, to share documents through the VWS.

The course had 14 student participants, aged 15-16, and 7 teachers, representing computer science, biology and geography, religion, history and philosophy, arts, music, and Finnish language. The students volunteered to participate in the course; they did not belong to a traditional classroom community, but were gathered together especially for this course. They were all quite high achieving students (according to the teachers), and they were meant to complete several, regular school courses by participating in the Culture course. It was the students' last spring in the obligatory comprehensive school. The teachers did not participate full-time in the course; they were responsible for other school courses as usual. The computer teacher was a coordinator of the whole course; other teachers participated as the experts and tutors of their own subject domain.

\subsection{Data collection}

The main data analysed in the study included the database notes posted by the participants to the VWS discussion forums during the course. The material was retrieved for analysis so that all the posted notes were arranged in a hierarchical order based on the reply structure; the first notes of each thread were listed in chronological order. The course was in Finnish; therefore, all the text examples presented in the article have been translated into English.

Five (out of seven) joint meetings in school were observed and videotaped by the researchers. One researcher participated in two teacher meetings, where the teachers designed the course. In addition, the researchers received various documents about the course accomplishments, including final works and written course evaluations from the teachers. This material and observational data from the meetings were used in complementary fashion to obtain an overview of the work process and to interpret the communication in the Web-based environment in a larger context. 


\subsection{Data analysis}

The methodological approach in the study was to answer the research questions by using rich qualitative data: database material, authentic documents and observations in the classroom and teacher meetings. There was no single piece of data or analysis that could exhaustively answer any question; rather, the results of separate analyses were combined to yield a multifaceted view of the virtual process from various perspectives.

Several quantitative measures of the features of the virtual discourse - number of messages, the distribution of messages in time and in the various forums, and length of discussion threads - were applied to the discussion forums in the VWS, in order to get an overview of the study group's virtual activity during the course.

The contents of the messages to the VWS database were analysed qualitatively using the methods of qualitative content analysis (Chi 1997) to evaluate the communication in the virtual discourse. The unit of analysis was one message. Messages were categorised according to the main content of the message text: what appeared to be the main purpose or object of the message in the discourse. The categories were derived from several preliminary analyses of the data in relation to the research questions. The following five categories were used in the final classification (examples of messages belonging to each category are reported in the Results section):

1) Subject of inquiry: These messages represented the students' problems, thoughts and explanations of the inquiry topics and subject domain concepts, descriptions of the subject of their inquiry, and the teachers' subject-specific guidance.

2) Process organization: Messages in this category included communication that was needed for organizing the work of separate small groups (arranging meetings, asking for help or comments, telling about information sources, making the agreement for task completion).

3) Community building: Messages in this category represented issues concerning the whole group, such as general discussion relating to the common purpose of the whole group (e.g. practising progressive inquiry and collaborative work, accomplishing inquiry about cultural issues), communication about the ways of using the virtual tools (e.g. organizing the forums, advice to use sensible message titles), and social aspects of the work (the need for a common meeting room, invitations and encouragement to participate actively in virtual work).

4) Assessment criteria: Messages in this category included questions, agreements and arguments about the rules for completing the final work, criteria for course grading and general timetables or deadlines.

5) Other issues: Messages put into this category included conversation about topics or school activity unrelated to the course tasks, and nonsense test messages written by the students in the practising phase.

Each message was classified in only one category according to its main content. The analysis was performed using ATLAS/ti-program. To analyse the reliability of classification, an independent coder classified approximately $17 \%$ of all messages (randomly selected message threads from a general forum and all the messages from one group forum); the coefficient for coder agreement (Cohen's Kappa) was .85, which was considered satisfactory. Those cases in which discrepancy emerged were encoded according to mutual agreement.

Methods based on social network analysis (Scott 1991) were used to study the structures of communication in the virtual activity, using the discourse data that consisted 
of the links between the messages: who communicated with whom by constructing message replies in the VWS discourse forums. The same methods have been used also in other studies of technology-supported collaborative learning (Lipponen et al. 2002, Hakkarainen and Palonen 2003) or in teachers' communication networks in a school (Bakkenes et al. 1999). All social networked analyses were performed using the Ucinet program.

The multi-dimensional scaling (MDS) technique was chosen to provide a graphical view of the communication patterns. The basic idea behind MDS is that of using the concepts of space and distance to map relational data. It includes an attempt to convert chart measures into metric measures (Scott 1991).

The participants' position in the virtual communication was analysed using Freeman's degree, which is a centrality measure. Centrality describes the importance or isolation of a member in the communication network. The degrees were counted from the sum of replies that the participants sent to others' messages (outdegree, indicates activity), and replies that the participants received from others (indegree, indicates 'popularity') in the VWS discussion forums. Freeman's betweenness value was used to show how often a given participant is found in the shortest path between two other students who do not directly interact with each other. Thus, it suggests the participant's position in regulating information flow within the communication network (Borgatti et al. 1996).

The measure of density was used to evaluate the general level of communication in the virtual discourse. Density is a simple way to measure a network: the more actors who have relationships with one another, the denser the network (Scott 1991); hence it indicates, here, the proportion of the intensity of interaction among the participants in the VWS discussions. Density was computed from a dichotomised matrix of replies (the participants had or had not sent replies to each other's messages, the frequency of replying did not matter) and it could vary from 0 to 1 . The density of the communication in the whole study group was counted both with and without the teachers' contributions in order to analyse the teachers' influence on the communication.

One methodological challenge was to combine the quantitative and qualitative measures to obtain a richer view of the collaboration structures in the virtual discourse. For that, we made separate matrixes for the sum of replies in each content category (Subject of inquiry, Process organization, Community building, Assessment criteria and Other issues) in the VWS, in order to find whether the centrality of the participants varied according to the content of the discourse. The degree measures were also used to examine the extent to which a whole graph representing participants' communication in VWS had a centralised structure or was distributed evenly through the whole network (Scott 1991).

\section{Results}

\subsection{The course design}

The overall actual, patterned process of the course - the structure and phases of the activity during the course - was reconstructed by combining the information received from the examination of database content, observed lessons and the teachers' planning sessions. Below is a short description of the main phases of the course.

Preliminary phase: The whole process started in the middle of December with a $1 \frac{1}{2}$-hour meeting in the school, when teachers introduced the course and its objectives to the students. Some students seemed to be insecure about the requirements of the course. 
Four high-achieving girl students withdrew from it in the first meeting. They stated that it is 'safer' to work in traditional courses because they wanted to get the highest degrees to their final middle school report. In the middle of January, the computer teacher gave the participants a training session for the VWS-environment. All students seemed reasonably competent in using technology and the virtual discussion tools. The reasons for using the collaborative tool were also discussed, and the general forum entitled 'Small talk' was founded for practising. The teacher gave the students a task to write their individual inquiry ideas to the VWS forum entitled 'Working plans and starting theories' before the next meeting. At the beginning of February, the philosophy teacher arranged a brainstorming session in the school. Students sketched the content of their inquiry work in the framework of various cultural dimensions (past-present-future, fact-fiction, individual-community, and so on). Also discussed were decisions about the small groups, tutoring teachers and school courses that the students would complete. After the meeting, the students continued the planning virtually in the VWS.

First course week: The students started their actual course work in the middle of February. In the first week, the computer teacher gave a lecture about progressive inquiry by introducing the successive elements of the inquiry process with a graph adopted from the researchers, depicting the following components: Setting up research questions, Constructing working theories, Critical evaluation, Searching deepening knowledge, Generating subordinate questions, and Constructing new working theories (see figure 1). The students formed small groups based on their interests and plans expressed in the VWS and the school courses they would complete. After forming the groups, the students decided the topic of their group's inquiry. The students formed 7 groups and formulated the following research topics: The biological effects of music (2 boys), Life in the Middle Ages (2 boys), Effects of genes and environment on a Finnish-Australian girls' life (2 girls), Japanese culture (1 girl alone), American Indian culture ( 2 boys), Comparison of Finnish and Canadian cultures ( 2 girls) and Aspects of religion and society ( 3 boys). Each group had a main, tutoring teacher, but all the teachers were meant to guide all students and give support especially to those students who were completing courses in their teaching subject. The students had chosen 2-6 school courses that they would complete by participating in the Culture course. At the end of the first week, the students had another working session in the computer lab. Their task was to write their group's research questions and first theories, and comment on other groups' plans in the VWS. 


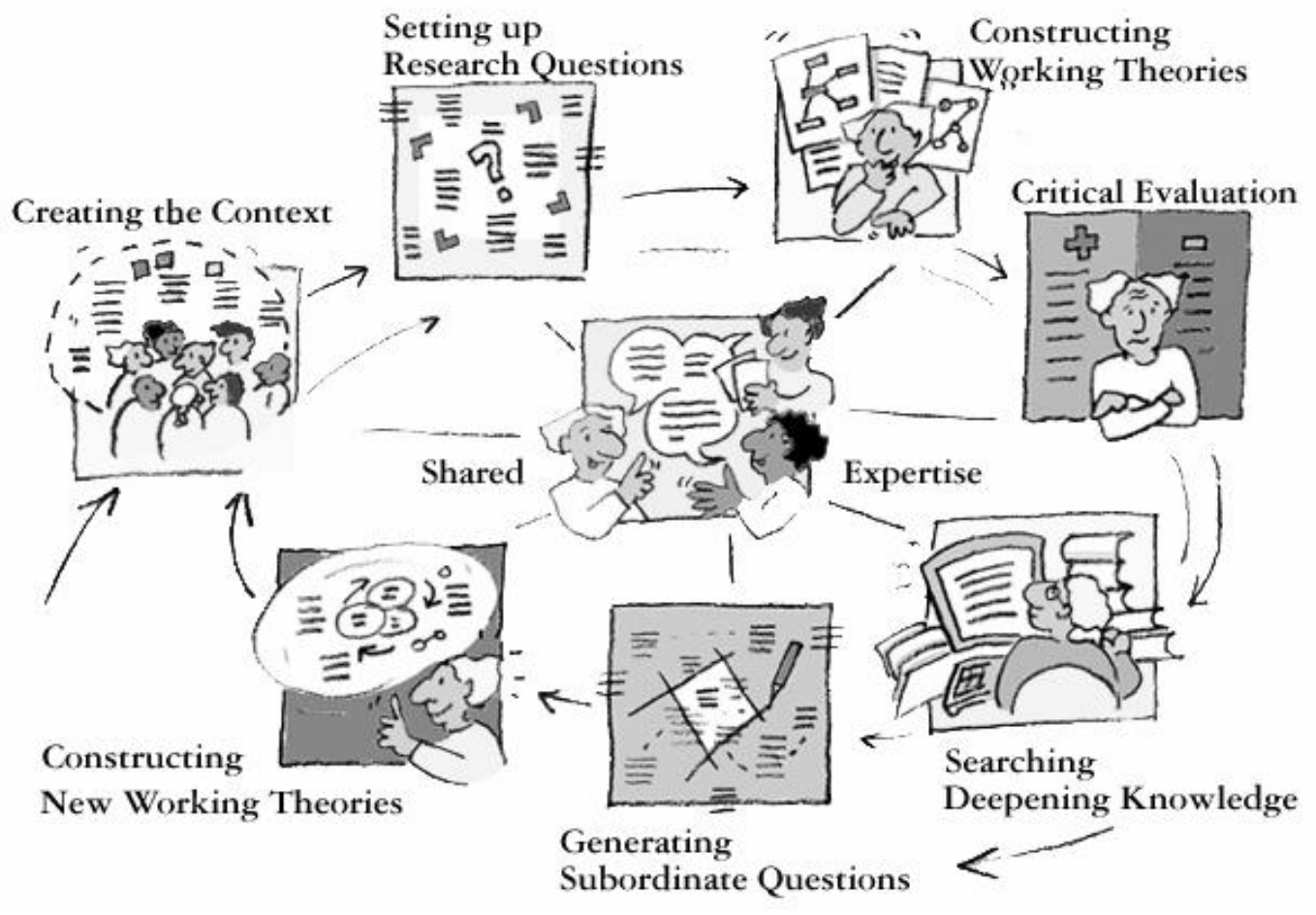

Figure 1. A graph presenting the elements of the progressive inquiry process.

From $2^{\text {nd }}$ to $6^{\text {th }}$ week: During the next five weeks, the students worked virtually and organized their group processes using the VWS. The students were guided to start the investigation of their research questions. Specific discussion forums for virtual planning were founded for each group, but they were open for everybody. During these weeks, the students processed their work in their respective group forums but also discussed issues in joint forums. In addition they had face-to-face meetings with their own group and the tutoring teachers.

$7^{\text {th }}$ and $8^{\text {th }}$ week: During the seventh week (at the beginning of April), there was a common face-to-face meeting where the groups commented on the state of each other's work. The teachers guided the students to think about the main points and new, interesting aspects in each group's inquiry. After that day, the small groups continued their process virtually, mostly finishing their final work and making plans about how to present it in the closing event. During the last week, there was a 4-hour closing event in the school meeting hall, where each group presented its final work in its own way. For example, the Middle Ages group had made a radio play, and the Canada group had written an imaginary diary of a schoolgirl who was visiting Canada as an exchange student. At the end of the week, the students were called to school, once more, to write their evaluation of the course for the researchers. Also the teachers were asked to complete a written evaluation of the course, its processes, its teaching, and students' results, and send it by email to the researchers; these evaluations were received from only three teachers.

In the Culture course, the students received a credit for 61 courses in all, according to the agreements; 4.4 courses per student on average. Based on the written evaluations, the 
students were content with their experience of virtual, collaborative learning, which forced them to practise self-direction and independent work. Some students criticised the vagueness of guidance given by the teachers, especially in the beginning of the inquiry process or related to the assessment criteria. The technical problems with the Web-based learning environment were the most-often-mentioned negative issues in the students' evaluations. The three teachers who completed the written evaluations mentioned the shortcomings in the structuring of the inquiry process and challenges of guiding the students during the virtual working periods. One teacher noted that the teachers themselves had different conceptions of progressive inquiry pedagogy.

\subsection{The extent and threading of the virtual discourse}

The participants posted 534 messages to the VWS database during the course (the minimum was 3 messages of a boy student; maximum, 81 messages of a male teacher). The students $(\mathrm{N}=14)$ posted 308 messages (Mean $=22.0, \mathrm{SD}=29.9)$, and the teachers $(\mathrm{N}=7)$ posted 226 messages $($ Mean $=32.3, \mathrm{SD}=26.0)$. The joint forum entitled 'Small talk' included 168 messages; the 'Plans and theories' forum, 113 messages; and the seven, group forums included 253 messages in all. In figure 2, one can see how the volume of messaging varied in discussion forums during the course.

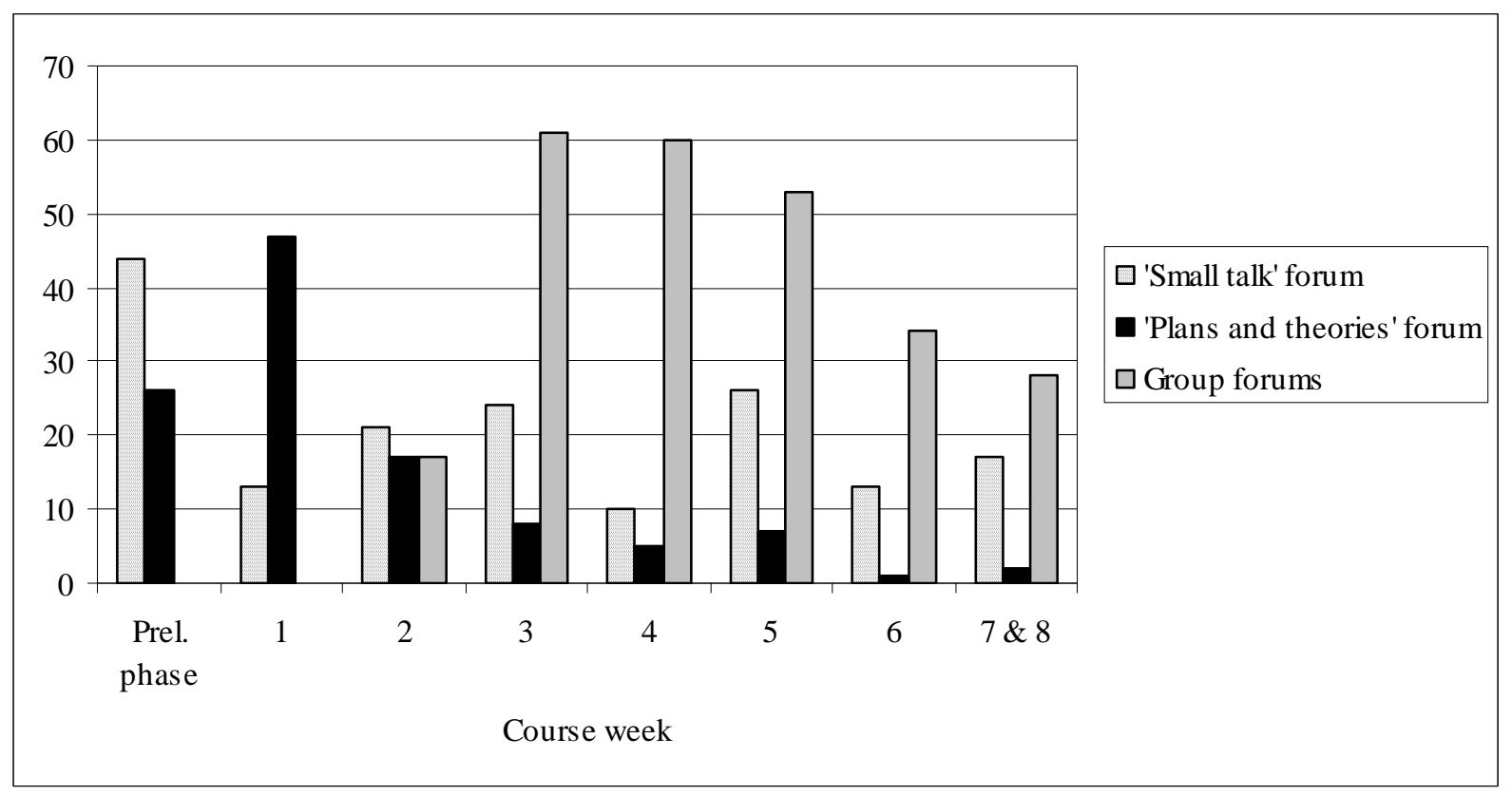

Figure 2. The number of messages in the separate discourse forums in each course week.

At the beginning of the process, only the two general forums were in use. As figure 2 shows, in the first, course week, the work was concentrated in the 'Plans and theories' forum according to the teachers' instructions. After the second week, the communication was mainly transferred to the group forums, where it was the most active in the middle of the course.

In all the virtual forums together, there were 218 top-level messages (41\% of all messages), those considered to be new initiations in the discourse. Of such messages, $44 \%$ (97) were isolated messages that did not have any replies following, and 56\% (121) were 
messages that had at least one reply; e.g., they had started a new discourse thread. The mean number of messages in discourse threads (in the threads that included at least two messages) was 3.63 ( $\mathrm{SD}=2.15)$. The longest thread included 14 messages, and only three threads had more than ten messages.

There were big differences in the use of each group's forum. The minimum number of messages in one forum was 13; maximum was 56. The mean number of messages in all group forums was 38.2 ( $\mathrm{SD}=14.9$ ). We also counted the number of messages that the students sent to the forums of other groups. Only 8 (out of 253) messages in the group forums were written by students from some other group. The students, clearly, did not contribute to other groups' inquiry work after the group forums were founded although they have been encouraged to do so (a notice from a videotaped lesson).

\subsection{The content of the virtual communication}

In the analysis, each message to the VWS discourse forums was assigned to one of the content categories described earlier. The original goal of the investigated course was to use the Web-based learning environment to support the sharing of knowledge during the inquiry process, which involves sharing the theories and explanations of cultural aspects. According to the content analysis, only 34\% (180) of the messages could be assigned to represent the Subject of inquiry category. The frequencies of other content categories were as follows: Process organization messages 24\% (129), Community building messages $20 \%$ (105), messages about Assessment criteria 13\% (67), and messages about Other issues 10\% (53).

The separate discourse forums obviously played several roles in the virtual communication. In the 'Small talk' forum, 50\% (84) of the messages were communitybuilding messages, and about $25 \%$ (41) were about other issues, unrelated to the common course goals. In the other joint discussion forum, the 'Plans and theories' forum, 64\% (72) of the messages were about the subject of inquiry. In the seven group forums, most of the communication was about the subject of inquiry $(42 \%, 105)$ or process organization (42\%, 107). The content of communication varied remarkably during the successive weeks of the course (see figure 3 ). 


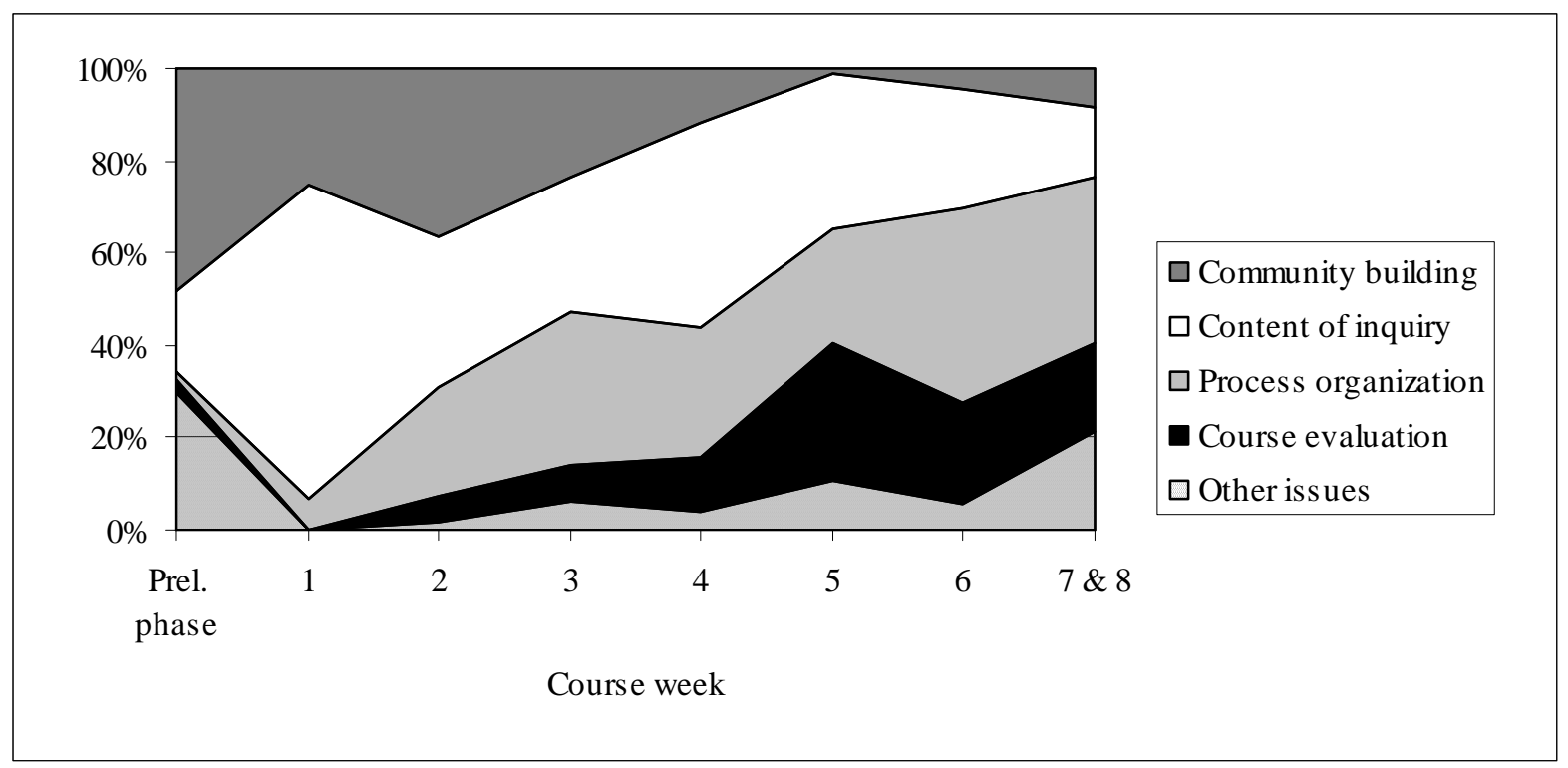

Figure 3. Change in the content of messages in the VWS discourse forums during the project.

In the virtual communication, issues that were interpreted as important for building up the learning community were dominant in the first half of the process, as shown in figure 3. The following discourse thread is an example of messages assigned to the category of community building; the messages reveal that some students were very competent with technical issues:

\subsection{About this Culture course (Boy student b8G)}

This is a fine system, but ... the possibility for real-time discussion is still missing. Maybe an IRC-channel? For instance \#alppila \#culturecourse \#alppila_culturecourse ... Then we, of course, need a 'bot' program to keep the channel going; does anyone have the possibility to supply one?

Waiting for answers...

18.01.2000 14.51.07 We need that later, we are not here all the time (Girl student g5F)

It is true that it would be useful because we need conversation, and it's not always sensible to use the telephone. This discourse forum is good, but it will probably be more differentiated; now this functions as a discussion medium. I support your idea!

The number of messages about other issues unrelated to the Culture course was high in the preliminary phase, probably because then the students and the teachers were practising their use of the Web-based environment. In the session at school, in which the participants were trained to use the VWS environment, $42 \%$ (27) of the posted messages were classified as community building messages, and $32 \%$ (21) as about other issues. The teachers did not direct the first practises with the VWS to subject-related inquiry work (a notice from a videotaped training session).

The number of messages in the subject of inquiry category was the largest in the first week of the course period, when the students were guided explicitly to define their plans, questions and first theories in their postings to the discourse forums. The following thread is an example of subject-related discourse: 
17.02.2000 19.37.53 Problems, group A (Boy student b9G)

1. How have the different cultures affected the development of humans?

2. How have the cultures spread out in the world and how have they affected each other?

3. Collaboration with Thomas:

What were the basic differences between the culture of American Indians and the western [European] culture?

What caused the disappearance of Indians?

How did the Indians' nature-based culture work?

4. What is the Islamic culture actually like? Is it as bad as the media represent it?

18.02.2000 13.46.40 A comment (Boy student b7E)

Good start, just continue!

18.02.2000 13.43.31 Large topics... (Girl student g5F)

Large topics... good topics... the effects of cultures on human development, you should consider what things to examine... the appearance, the ways of life, the economic state, environment... it might be difficult to examine everything.

Effects on each other or the spreading... a very good topic, but it is quite difficult, at least those effects... should you examine some special culture?

Indians... on the other hand, if you have these large topics also, that topic is quite restricted to a certain place and it is also a small one... but it is also interesting.

About that Islamic religion I cannot say much.

Especially later in the course, most of the messages assigned to the Subject of inquiry category were about shaping the content of the final work. The following is an example of the message from the Australian group:

\subsection{Answer Sorry, if...(Girl student g1B)}

... sorry that we did not discuss [things] with you, before the course, including the topics of religion in our work. But we have a lot of material about that topic. First we are going to tell about the religion of aboriginals, totems and 'dreamtime' and its myths. In addition we are going to compare their attitudes towards life with ours, and to examine how they experience our religion and our God. We thought also to include something about Jesus...

The teachers' subject-related messages were mostly guidance for the inquiry process. For example:

29.02.2000 08.39.28 I want information (Male teacher M1D)

Do you remember that I asked the other day for a list of your beliefs and conceptions about the Middle Ages. I thought that BEFORE you start to read Litzen's book etc., you should write your conceptions about what the Middle Ages are, either as a mind map or as an idea list. It can be a quite long list. Is Xena medieval? What about Conan? You understand the usefulness of this, don't you? Don't be afraid of possible 'mistakes' - in this work you cannot make them.

According to the analysis, very little of the subject-specific discourse was of a highlevel conceptual nature or contained proposed theoretical explanations; rather there was 
reporting or commenting on the themes under examination. It appears that the students and the teachers did not actually use the Web-based environment very much as a forum for collaborative knowledge building or for the sharing of knowledge productions. Most of the knowledge construction, to the extent it occurred, probably happened in face-to-face meetings with the group members and the tutoring teachers, not through the VWS. Participants might also have used e-mail or a chat forum for mutual communication inside the groups, but such information was not available for the researchers.

In the VWS discourse forums, the number of process organization messages increased after the small groups were formed, and it continued to increase towards the end of the course. Many of the process organization messages handled daily, practical matters, such as arranging meetings or explaining activities to be done. The planning of the groups' presentation in the closing event was one dominant theme in these messages. The following thread is an example of process organization discourse in the Music group:

09.03.2000 17.09.11 How are you (Female teacher F2B)

What is the situation in the research about the biological effects of music, or are you still planning it? Regards, Susan

09.03.2000 22.48.04 Thanks, very well...(Boy student b2A)

We have started the research, but because Mike got sick during our music activity, we had to stay in the same phase for a while.

13.03.2000 10.32.44 Sharing the work (Female teacher F4F)

Would it be useful to share your work, so that if the one is sick, the other can somehow continue the work before the time runs out.

Toward the end of the course, questions about assessment criteria, such as timetables, rules and course evaluation started to interest the students more, and it appears to be one of their concerns that the criteria had not been clearly specified in the beginning of the process. The original goals of the course had been to promote multidisciplinary inquiry, but towards the end, the teachers and the students had to enter into agreements about course completion according to the curriculum. One of the longest and 'hottest' discourse threads (12 messages) in the Web-based environment was about assessment criteria and deadlines for the work. For example, one girl student had problems with understanding the idea of getting comments and revising the work:

30.03.2000 08.03.12 Returning the work (Male teacher M1D)

Well, simply: You bring, on the $5^{\text {th }}$ day of the month, the work you have. Some groups may be so ready, that nothing can be added to the work. Most of the works consist of several parts. Perhaps, at least some parts could possibly be improved? Maybe there is something to add, or to correct? Why do you think that you cannot change the work that has been returned? This is not a final exam. Peter

01.04.2000 16.06.18 It cannot be changed, and that's it! (Girl student g1B)

Our work is either ready, or then it is not. It is a sound whole, a narrative, and there are two options: either we return it as a whole or we don't return it at all.

Two girl students even refused to come to the evaluation meeting after the course because they had not yet come to an agreement with the teachers about their course grades (information received from the teachers). There was an obvious contradiction between the traditions and demands of the assessment practises in school and the new goals of virtual, collaborative inquiry work. 
The evaluated course gave a good opportunity to compare students' and teachers' contribution to a collaborative inquiry process because there were so many teachers involved in comparison to the number of students (although some teachers' contribution to the virtual discourse was rather small). In table 1 are presented the general frequencies and proportions of each content category in the students' and teachers' messages. The general content profiles did not differ much (the correlation of the distribution was 0.71). According to $\chi^{2}$-test there was a significant difference between the groups $(\chi 2=26.8, \mathrm{df}=$ $4, \mathrm{p}<0.001)$. Cell-specific exact tests were carried out in order to examine whether the observed frequencies in each cell deviated from what could be expected by chance alone.

Table 1. The contents of the students' and the teachers' messages in the VWS discourse forums.

\begin{tabular}{ccccc}
\hline & \multicolumn{2}{c}{ Students $(\mathrm{N}=14)$} & \multicolumn{2}{c}{ Teachers $(\mathrm{N}=7)$} \\
\cline { 2 - 5 } Content category & $\mathrm{f}$ & $\%$ & $\mathrm{f}$ & $\%$ \\
\hline Subject of inquiry & 104 & 34 & 76 & 34 \\
Process organization & $55^{*}$ & 18 & $74^{\dagger}$ & 33 \\
Community building & 65 & 21 & 40 & 18 \\
Assessment criteria & 40 & 13 & 27 & 12 \\
Other issues & 44 & 14 & $9^{*}$ & 4 \\
\hline Total & 308 & 100 & 226 & 100 \\
\hline Note. Significance tests are based on binomial probability estimations (Bergman and El-Khouri 1987); \\
* = Observed frequency smaller than expected by chance alone (p < 0.01); \\
$\dagger=$ Observed frequency larger than expected by chance alone $(\mathrm{p}<0.01)$.
\end{tabular}

The results of table 1 indicate that both the teachers and the students took responsibility for the virtual work. A quite expected result is that the students had more messages than teachers, on other than course-related issues. What is noteworthy is that the teachers used the Web-based environment a great deal for supporting the students' process organization, in addition to providing advice related to the subject of inquiry. Another indication of the teachers' strong efforts to organize the group work through the Web-based environment was the high proportion of the teachers' messages posted to the small groups' discourse forums. Teachers wrote 57\% (145) of the 253 messages in the group forums. The content of the process organization messages in the VWS and other information received from the course indicate that that the students themselves did not use the Web-based environment for intra-group collaboration, but did the actual group work in face-to-face meetings. The Web-based environment was used mainly for sharing issues concerning all participants or for communicating with the teachers.

\subsection{Interaction patterns in the virtual communication}

Methods based on social network analysis were used to study the patterns of interaction in the students' and teachers' virtual activity. The main measures of interaction activity were numbers of sent (outdegree) and received (indegree) replies. For the students, the average outdegree was 13.4 ( $\mathrm{SD}=12.27)$; indegree was $16.4(\mathrm{SD}=10.54)$. For the teachers, the average outdegree was 20.0 ( $\mathrm{SD}=20.8)$; indegree was $14.0(\mathrm{SD}=13.27)$. The measures show that the teachers were, on average, much more active than the students in replying to others' messages.

The density of interaction was counted for the whole study groups' virtual discourse, both with and without the teachers' contribution. The density of the interaction in the whole network was $0.35(\mathrm{SD}=0.48)$ for asymmetric data, and $0.50(\mathrm{SD}=0.50)$ for symmetric 
(reciprocal) data, which is not very high, but not very low either. The density was almost the same when counted without the teachers' participation, which indicates that the teachers' role was not crucial for the density of the virtual interaction. We also examined the extent to which a whole graph representing members' virtual interaction had a centralised structure. The results of the analysis indicated that the interaction was not very centralised: it was $37 \%$ and $21 \%$ in the case of sent and received replies, respectively. It follows that the communicative efforts were distributed among a relatively large number of participants, but the sending of replies was more centralised on certain participants than was the receiving of replies.

To examine the nature of interaction patterns in the virtual communication more closely, the results of qualitative content analysis and the measures of social network analysis were combined. Separate reply matrixes were constructed for the five, content categories (Subject of inquiry, Process organization, Community building, Assessment criteria, and Other issues), and network centralisation measures (based on the outdegree and indegree measures) were counted separately for those five, different, content networks (table 2).

Table 2. The centralisation of the communication networks, based on the different contents of the replies.

\begin{tabular}{cccc}
\hline Content of & Number of notes & Centralisation of the network (\%) \\
\cline { 2 - 4 } communication & $f$ & Outdegree & Indegree \\
\hline Subject of inquiry & 180 & 79.5 & 37.5 \\
\hline Process organization & 129 & 80.0 & 48.5 \\
\hline Community building & 105 & 51.8 & 41.3 \\
\hline Assessment criteria & 67 & 49.8 & 44.5 \\
\hline Other issues & 53 & 14.3 & 30.0 \\
\hline
\end{tabular}

As can be inferred from table 2, the centralisation of the network varied substantially in various content areas, and it was low only in the content category, 'Other issues'. Communication, and particularly sending of replies, was very centralised, especially on the subject of inquiry and process organization issues, which indicates that in the virtual communication, there were participants who were active in commenting others' ideas concerning the inquiry task.

The position of each participant in the virtual communication network was also analysed separately. To begin with, a multi-dimensional scaling (MDS) analysis was performed to the discourse data of virtual forums in order to get an overall notion of the interaction positions. Because previous analyses revealed that the students did not much use the group forums for advancing their own or other groups' work, the MDS graph was constructed only from the discourse data of the two, joint forums. The intensity of interaction was used as a measure of closeness: the more replies the students sent to or received from certain participants, the closer they are situated in the MDS map (see figure 4). The analysis is calculated with a symmetric matrix, where received and sent replies are summed up. The stress value, a measure of the quality of the MDS map, was at a satisfactory level (0.132). 


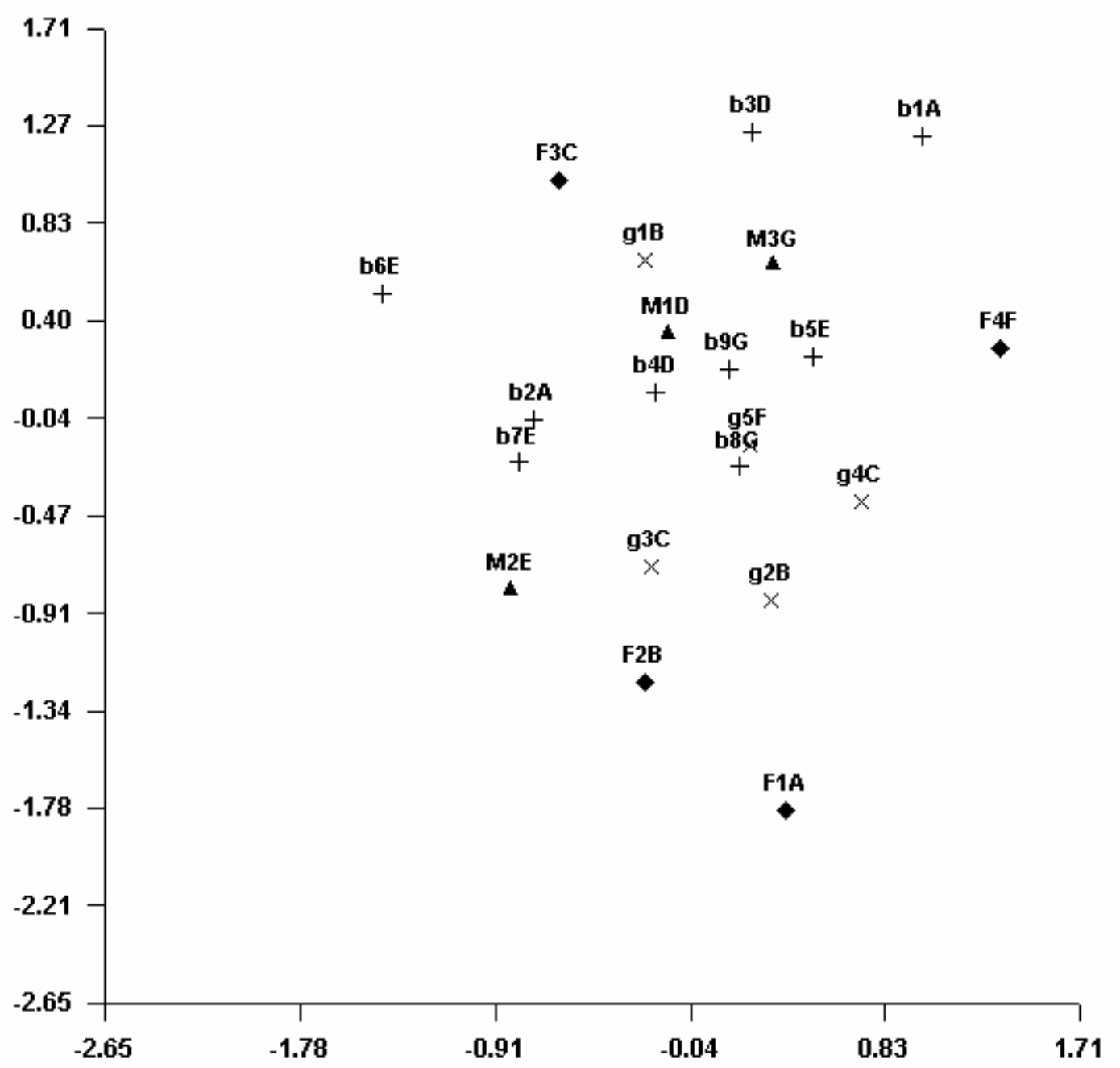

Figure 4. The structure of communication in the virtual discourse ( $g=$ Girl student, $\mathrm{b}=$ Boy student, $\mathrm{F}=$ Female teacher, $\mathrm{M}=$ Male teacher; the letters $\mathrm{A}-\mathrm{G}$ indicate the groups).

Figure 4 reveals that there appear not to have been any distinguishable subcultures of interaction (there is not any group of members who are clearly separate from others). Two teachers are in a rather central position; other teachers are more on the periphery. Three boy students are in a peripheral position in the interaction graph, but at the centre of the joint interaction, one finds only students.

In table 3 are presented the basic centrality measures of each member in the whole virtual communication, including the group forums (the extent of each member's participation and the sum of sent and received replies in every content network). As can be seen from table 3, the most central and active member varies somewhat according to the content of communication, indicating that the members took different roles in the virtual communication. The most active male teacher (M1D) and two boy students (b8G and b9G) were central in almost every content area of the discourse. One girl student was central, interestingly, in the measures counted from all virtual communication, and in the discourse on assessment criteria and other issues, unrelated to the course goals. Her betweenness measure is rather high in comparison with most other members, which indicates that she commented on some members who did not comment on each other directly in the virtual 
forums. Three, boy students (b1A, b3D and b6E) were very passive, which is apparent also in the MDS graph (figure 4).

Table 3. Activity and centrality measures for all the members in the virtual communication ( $\mathrm{g}=$ Girl student, $\mathrm{b}=$ Boy student, $\mathrm{F}=$ Female teacher, $\mathrm{M}=$ Male teacher; the letters $\mathrm{A}-\mathrm{G}$ indicate the groups). The highest four values are bolded in every measure.

\begin{tabular}{|c|c|c|c|c|c|c|c|c|c|}
\hline \multirow[b]{2}{*}{$\begin{array}{l}\text { Parti- } \\
\text { cipant }\end{array}$} & \multicolumn{4}{|c|}{ Overall virtual activity } & \multicolumn{5}{|c|}{ Sum of replies in each content network } \\
\hline & $\begin{array}{c}\text { Messages } \\
\text { written }\end{array}$ & $\begin{array}{l}\text { Sent replies } \\
\text { (outdegree) }\end{array}$ & $\begin{array}{l}\text { Received } \\
\text { replies } \\
\text { (indegree) }\end{array}$ & $\begin{array}{l}\text { Between- } \\
\text { ness }\end{array}$ & $\begin{array}{c}\text { Subject of } \\
\text { inquiry }\end{array}$ & $\begin{array}{c}\text { Process } \\
\text { organi- } \\
\text { zation }\end{array}$ & $\begin{array}{c}\text { Commu- } \\
\text { nity } \\
\text { building }\end{array}$ & $\begin{array}{c}\text { Assess- } \\
\text { ment } \\
\text { criteria }\end{array}$ & $\begin{array}{l}\text { Other } \\
\text { issues }\end{array}$ \\
\hline b1A & 5 & 3 & 2 & 1.4 & 3 & 1 & 0 & 0 & 1 \\
\hline $\mathrm{b} 2 \mathrm{~A}$ & 12 & 8 & 10 & 4.7 & 5 & 2 & 3 & 0 & 8 \\
\hline g1B & 45 & 26 & 28 & 13.2 & 16 & 3 & 6 & 21 & 10 \\
\hline g2B & 10 & 7 & 6 & 1.3 & 3 & 1 & 5 & 0 & 4 \\
\hline $\mathrm{g} 3 \mathrm{C}$ & 13 & 6 & 16 & 5.5 & 9 & 7 & 0 & 4 & 0 \\
\hline $\mathrm{g} 4 \mathrm{C}$ & 7 & 2 & 12 & 1.2 & 9 & 3 & 1 & 0 & 1 \\
\hline b3D & 5 & 0 & 6 & 0.0 & 5 & 1 & 0 & 0 & 0 \\
\hline $\mathrm{b} 4 \mathrm{D}$ & 35 & 21 & 23 & 2.0 & 14 & 11 & 18 & 0 & 2 \\
\hline b5E & 26 & 11 & 20 & 7.0 & 13 & 2 & 12 & 0 & 4 \\
\hline $\mathrm{b} 6 \mathrm{E}$ & 3 & 0 & 4 & 0.4 & 3 & 0 & 0 & 0 & 0 \\
\hline b7E & 19 & 11 & 12 & 1.5 & 5 & 9 & 2 & 1 & 6 \\
\hline g5F & 38 & 23 & 25 & 6.1 & 24 & 16 & 5 & 3 & 1 \\
\hline $\mathrm{b} 8 \mathrm{G}$ & 48 & 31 & 31 & 21.1 & 20 & 14 & 20 & 6 & 5 \\
\hline b9G & 53 & 38 & 34 & 13.5 & 33 & 14 & 18 & 2 & 2 \\
\hline F1A & 7 & 1 & 3 & 0.7 & 2 & 1 & 1 & 0 & 0 \\
\hline F2B & 31 & 9 & 12 & 6.5 & 10 & 4 & 3 & 5 & 0 \\
\hline F3C & 10 & 6 & 7 & 0.0 & 2 & 1 & 2 & 5 & 2 \\
\hline M1D & 81 & 62 & 43 & 8.8 & 33 & 32 & 20 & 12 & 6 \\
\hline M2E & 19 & 11 & 9 & 5.4 & 6 & 7 & 6 & 1 & 1 \\
\hline $\mathrm{F} 4 \mathrm{~F}$ & 39 & 23 & 10 & 3.9 & 13 & 18 & 1 & 1 & 0 \\
\hline M3G & 39 & 28 & 14 & 5.9 & 20 & 11 & 9 & 3 & 1 \\
\hline $\begin{array}{l}\text { Mean/ } \\
\text { students }\end{array}$ & 22.8 & 13.4 & 16.4 & 5.6 & 11.6 & 6.0 & 6.4 & 2.6 & 3.1 \\
\hline $\begin{array}{l}\text { Mean/ } \\
\text { teachers }\end{array}$ & 32.3 & 20.0 & 14.0 & 4.5 & 12.3 & 10.6 & 6.0 & 3.9 & 1.4 \\
\hline
\end{tabular}

Two teachers in particular (the most active male teacher M1D, and the female teacher, F4F, who was the principal organizer of the whole course) had an active role in discussing process organization issues, and teacher $\mathrm{M} 3 \mathrm{G}$ engaged in a great deal of communication on the subject of inquiry issues. Other teachers were not very active contributors to the virtual discourse, which might have followed from the original design of the course: Some teachers' role was to guide students only when needed, related to their domain of expertise.

On the basis of both table 3 and the MDS graph in figure 4 one may conclude that two boy students (b8G and b9G) were especially central actors in the virtual interaction: They used the Web-based learning environment actively in their inquiry work, commented on others' ideas frequently in the joint forums, and participated in the discussions of all 
content areas. The following is an example of a message written by the boy student b9G as a comment on the inquiry plans of a student in the group studying aspects of religion and society:

18.02.2000 13.53.14 More questions ...(Boy student b9G)

It would also be interesting to know how various stages of religion affect human activity and thinking, what is the effect of administration in religious life, and also a little bit aside of the topic, what elements are similar in different religions... The effect of religion on language is a very interesting question ...

\section{Discussion}

In the present study, we investigated how middle school students and teachers succeeded in accomplishing a virtual collaborative inquiry. We intended to document the challenges that the teachers encountered in applying the new ways of working and to find indications of emerging, innovative, pedagogical practises. In the following, we discuss both the successes of the pedagogical implementation and the problems and challenges in the course relating to the original goals of progressive inquiry and virtual collaboration. It is worth reiterating that the investigated school course was by no means a typical example of implementing Web-based technology and collaborative practices in school. The results are not easily generalisable because of the highly selective student group and the unusually high teacher-student ratio, but we believe they are suggestive of emerging phenomena in the present situation of massive educational challenge and change.

\subsection{Successes in the pedagogical implementation}

Generally, the evaluated, school course succeeded in many ways. The theme was genuinely multidisciplinary; several teachers collaborated in the implementation; the Web-based learning environment was in relatively active use; and the virtual working setting gave a genuine reason for the participants to use the technology for communication. The students took much responsibility for their work and completed many middle school courses from several subject domains during the course. The final works of the student groups were large, multidisciplinary and unique cultural products.

The traditional student-teacher roles changed in the virtual communication. The teachers gave up their role as knowledge deliverers, and actually some of the students were the most central actors in the virtual interaction. Those central students acted in an expertlike way, taking responsibility for helping decide issues of shared goals and social conventions in the virtual communication, and commenting on other students' work. Using the terms introduced by Scardamalia (2002), we may say that those students demonstrated collective cognitive responsibility in their behaviour.

\subsection{Progressive inquiry goals not fully achieved}

If the implementation of the course is examined critically against the original goals of progressive inquiry, clear shortcomings can be identified. The features of progressive inquiry and joint knowledge construction were present in the students' work at the beginning of the course when the teachers explicitly directed the students' virtual collaboration towards the formulation of research questions and theories about the cultural phenomena. Later in the course, the students and teachers generally did not use the Web- 
based learning environment for deepening epistemic inquiry or sharing of knowledge objects; their communication changed towards the organization of practical, taskaccomplishment issues within the student groups. Probably the organization of the course in sub-groups that had very divergent topics tended to undermine the emergence of a joint object for knowledge work, which reduced the necessity for knowledge sharing in the whole learning community (Hakkarainen et al. 2004). Also the Web-based system used did not have very sophisticated tools for higher-level knowledge building: the main collaborative tool was a threaded discussion forum, which did not allow sharing and modifying of joint digital artefacts.

The activity in the course, as it developed, became more like project-based learning, where the formation of the end product starts to dominate as the object of the work, not the advancement of ideas and solving of knowledge problems (Bereiter and Scardamalia 2003). More attention should have been given to the conceptual and theoretical goals of inquiry in addition to the preparation of the final work. Law et al. (2002) reported similar conclusions in their multiple-case study of ICT and innovative practises: The nature of students' efforts and learning outcomes was dependent on whether the students were encouraged to engage in working with ideas and understanding, not with tasks and activities.

The students would apparently have needed more accurate structuring and constant support throughout the progressive inquiry process. The teachers taught progressive inquiry principles to the students by lecturing about the model in the beginning of the course. Further, they mainly emphasised students' own active working and self-regulation without demonstrating exemplary ways to support and direct the inquiry activity during the process, as if they assumed that students would learn the practices just by hearing about them. Perhaps this suggests something about the teachers' inexperience in teaching working practices in addition to delivering content knowledge, especially in secondary-level classrooms. Similar results were reported in our other study (Lakkala et al. 2005) investigating eight classroom cases of implementing progressive inquiry in primary and secondary education. This difficulty of instructing and supporting students in self-direction and learning higher-order metacognitive strategies relates to the more general problem of scaffolding collaborative inquiry learning, a widely discussed issue in recent educational research: How does one support groups of learners to succeed in tasks too difficult for them without help so that they finally learn to master the skills by themselves and the support can be faded away (Tabak 2004, Lakkala et al. 2005, Puntambekar and Kolodner 2005).

\subsection{Challenges related to virtual collaboration}

The actualisation of virtual collaboration was another interesting element of the course because usually virtual or distance working is not applied at the middle-school level. The student groups did not use the virtual forums for collaboration as actively as we anticipated. There were some technical problems in the functioning of the Web-based environment during the course, but it does not appear that the pattern of virtual work was mainly the result of technical issues. All participants had adequate technical skills to use the Webbased learning environment, and some students turned out to be very experienced in using discussion forums and chat tools. Some students were rather critical of the technical possibilities of the tool, which may be one reason for the relatively low usage of the tool during the virtual working phases.

The great number of messages concerning community-building issues at the beginning of the course indicates the necessity (asserted by Schuler 1996) for participants 
to come to agreement on the collective work habits in a starting virtual community. Also, the great number of process organization messages, especially in the group forums, indicates that virtual work requires a channel through which the participants can coordinate their joint work; in face-to-face situations, such issues are communicated verbally. In that sense, the virtual communication during the course resembled the patterns of a design process, as in a virtual project by university textile students studied by Lahti et al. (2003), where over $20 \%$ of students' messages to a virtual learning environment were about process organization.

All students did the final work and received credits from several courses, but some students were very passive in the virtual communication, and the teachers had problems with finding ways to guide them during the distance-working periods. On the evidence, the teachers likewise failed sufficiently to foster the students in bringing together various phases of their inquiry work into the Web-based environment for feedback, notwithstanding the original purpose was to share the ideas and plans virtually throughout the course. The unevenness of the students' participation in virtual work and problems with student guidance are results that have also been reported in other progressive inquiry studies of our research group (Lakkala et al. 2005, Lipponen et al. 2002, Veermans et al. 2005). If the participants had been more low-achieving students, they would have needed even more support and guidance.

\subsection{Tensions between progressive inquiry pedagogy and school curriculum}

The analysis of the course progression and the content of the virtual communication revealed that there were tensions between the inquiry pedagogy and the institutional practises of the school, particularly as regards curriculum and assessment. Even though the school was advanced in pedagogical development work, practises of this kind were still something special, not normal routine embedded in the entire learning culture of the school. The investigated students had two, demanding, new challenges at the same time: progressive inquiry and virtual collaboration. The course was the first time for all the student participants to work in this way, and it was conducted in the last spring of their 9year comprehensive school career.

The incompatibility of the new working methods and the assessment criteria of the school system emerged as an important issue. To begin with, some students withdrew from the whole course because they felt uncertain about getting the highest degrees in that way. The time of the course was not ideal for radical experimentation because the students were, understandably, concerned about their grades in the final, middle school report. In addition, in spite of the high-level goals of the course for accomplishing collaborative multidisciplinary inquiry, the teachers still graded students according to domain-specific courses in the official curriculum. The requirement of individual and domain-specific grading was in contradiction with the goals and criteria of collaborative working, and it drew the students' attention to the grades instead of the ideas and knowledge produced during the inquiry process - an issue whose gravity we and the teachers did not appreciate at the time. Roschelle et al. (2000) argued that such mismatch between the focus of assessment and the kinds of higher-order learning supported by technology is one of the greatest barriers in introducing effective technology applications in classrooms. The teachers should have designed the assessment criteria, in agreement with school authorities, so as to ease grade pressure, assuring all who participate actively, a high grade irrespective of the actual product. 


\section{Conclusions}

The evaluated school course showed that it is possible to surpass many structural constraints in the school if the teachers and students are open-minded and willing to try new innovations. However, the transformation of educational practises is not a simple task. The institutional norms of school affect the introduction of pedagogical innovation, and those institutional norms also need to be transformed if one wants to change school education with technology. In general, it is desirable for students to have a possibility to practise new, challenging working methods at school, little by little, without the demands of grading and instant success. Growing up to a modern, knowledge-building culture has to happen gradually throughout whole school life.

Although we may question whether it is reasonable to implement distance-working settings at the middle-school level in general, the self-directed virtual working with Webbased technology as such was apparently not too demanding for the students in the investigated case, regardless of some technical problems. The most difficult challenge for the students -and also for the teachers - appears to have been to understand the epistemic nature of the inquiry process and to find effective ways to implement it. It is essential that one convey that the primary goal of progressive inquiry is to focus on the continuous improvement of knowledge objects (questions, ideas and explanations) collaboratively, not simply production of a final work. As Paavola et al. (2002) stated, the promotion of students' knowledge-creation practises requires that the teachers build up - indeed, create an appropriate epistemological infrastructure in addition to the social infrastructure whose importance was proposed inter alia by Bielaczyc (2001). 'Epistemological infrastructure' refers to individual and collective attitudes towards knowledge and practices of knowledge advancement.

In the present case, the teachers themselves were novices in undertaking progressive inquiry; it challenged their skills and understanding of knowledge-creating inquiry. The transformation of school education with modern Web-based technology probably requires changes both in the teachers' conceptions of learning and knowledge and their skills in implementing advanced practises. The suitable preconditions for promising pedagogical development with technology include the teachers' deliberate efforts to develop their pedagogical practises, their reflection of those efforts and experiences, and the supportive professional culture of the school (Dexter et al. 1999, Ilomäki et al. 2004). The teachers' efforts promoted creation of these preconditions in the investigated case, despite the difficulties. It would be fruitful to investigate the subsequent implementations of this pedagogical innovation in the same teacher community.

Although the school was not a typical one, we believe the results are intriguing. The case was chosen as the object of research because of its innovative nature. Schools have to get rid of the conventional model of one teacher teaching a fixed study group behind a closed classroom door, in order to properly answer to the expectations that society sets on the development of schools in the future. We submit that the evidence of present case suggests new models and ideas to the discussion of transforming school education with modern technology and advanced pedagogical practices.

\section{Acknowledgements}

The research reported in the article was part of the Educational technology project of the City of Helsinki in the years 1995-2000. We want to thank all teachers and students who 
participated in the investigated course and all the persons who have helped improve the present article, especially Jiri Lallimo, Kai Hakkarainen, Sami Paavola and Hal White. We also wish to thank two anonymous reviewers for their useful comments on an earlier version of this article. The study was supported partially by a grant from the Research Council of Culture and Society of the Academy of Finland (\#1206380) and the first author was supported by a personal grant from the Academy of Finland in the years 2004-2005 (\#105205).

\section{References}

BAKKENES, I., DE BRABANDER, C. and IMANTS, J., 1999, Teacher isolation and communication. Network analysis in primary school. Educational Administration Quarterly, 35, 166-202.

BARAB, S.A., 2003, An introduction to the special issue: Designing for virtual communities in the service of learning. The Information Society, 19, 197-201.

Bereiter, C. and SCARDAmalia, M., 1993, Surpassing Ourselves: An Inquiry into the Nature and Complications of Expertise (Chicago: Open Court).

Bereiter, C. and ScARdamalia, M., 2003, Learning to work creatively with knowledge. In Powerful Learning Environments: Unravelling Basic Components and

Dimensions, E. De Corte, L. Verschaffel, N. Entwistle and J. van Merriënboer (Eds.) (Oxford: Elsevier Science), pp. 55-68.

BIELACZYC, K., 2001, Designing social infrastructure: The challenge of building computersupported learning communities. In European Perspectives on Computer-Supported Collaborative Learning, P. Dillenbourg, A. Eurelings and K. Hakkarainen (Eds) (Maastricht: Maastricht McLuhan Institute), pp. 106-114.

Borgatti, S., Everett, M. and FreEMAn, L., 1996, UCINET IV Version 1.64 Reference Manual (Natick: Analytic Technologies).

Bransford, J., Brown, A. and Cocking, R., 2000, How People Learn: Brain, Mind, Experience, and School (Washington: National Academic Press). 
Candela, A., Rockwell, E. and Coll, C., 2004, What in the world happens in classrooms? Qualitative classroom research. European Educational Research Journal, 3, 692-713.

CHI, M.T.H., 1997, Quantifying qualitative analyses of verbal data: A practical guide. The Journal of the Learning Sciences, 6, 271-315.

DeXTER, S.L., ANDERSON, R.E. and BECKER, H.J., 1999, Teachers' views of computers as catalysts for changes in their teaching practice. Journal of Research on Computing in Education, 31, 221-239.

Engeström, Y., EngeSTRÖM, R. and SunTiO, A., 2002, Can a school community learn to master its own future? An activity-theoretical study of expansive learning among middle school teachers. In Learning for Life in the 21st Century: Sociocultural perspectives on the future of education, G. Wells and G. Claxton (Eds.) (Oxford: Blackwell), pp. 211-224.

GrANSTROM, K., 1996, Private communication between students in the classroom in relation to different classroom features. Educational Psychology, 16, 349-364.

GuZDIAL, M. and TURNS, J., 2000, Effective discussion through a computer-mediated anchored forum. The Journal of the Learning Sciences, 9, 437-469.

HAKKARAINEN, K., 2003, Emergence of progressive inquiry culture in computer-supported collaborative learning. Learning Environments Research, 6, 199-220.

Hakkarainen, K. and Palonen, T., 2003, Patterns of female and male students' participation in peer interaction in computer-supported learning. Computers \& Education, 40, 327-342. 
Hakkarainen, K., Palonen, T., Paavola, S. and Lehtinen, E., 2004, Communities of networked expertise: Professional and educational perspectives (Amsterdam: Elsevier).

HANNAFIN, M.J. and LAND, S.M., 1997, The foundations and assumptions of technologyenhanced student-centered learning environments. Instructional Science, 25, 167202.

HINTIKKA, J., 1999, Inquiry as Inquiry: A Logic of Scientific Discovery. Selected Papers of Jaakko Hintikka, Volume 5 (Dordrecht: Kluwer).

HOFER, B.K., 2004, Epistemological understanding as a metacognitive process: Thinking aloud during online searching. Educational Psychologist, 39, 43-55.

Hogan, K., NAStAsi, B. and Pressley, M., 1999, Discourse Patterns and Collaborative Scientific Reasoning in Peer and Teacher-Guided Discussions. Cognition \& Instruction, 17, 379-432.

ILOMÄKI, L. and LakKala, M. (Eds.), 2003, Computers in School's Daily life. A Final Report of the Educational Technology Project of City of Helsinki 1996-2000, City of Helsinki Publication Series, A3:2003 (Helsinki: City of Helsinki Education Department).

ILOMÄKI, L., LAKKALA, M. and LeHTINEN, E., 2004, A case study about ICT adoption within a teacher community at a Finnish lower secondary school. Education, Communication \& Information, 4, 53-69.

Kirschner, P., StRiJbos, J., Kreijns, K. and BeERS, P.J., 2004, Designing electronic collaborative learning environments. Educational Technology Research \& Development, 52, 47-66. 
KozmA, R.B., 2003, Technology and classroom practices: An international study. Journal of Research on Technology in Education, 36, 1-14.

Lahti, H., SeitamaA-Hakkarainen, P. and Hakkarainen, K., 2003, Piloting participatory designing within a collaborative learning environment. Journal of Interactive Learning Research, 14, 185-207.

LaKKala, M., LALlimo, J. and HAKKARAINEN, K., 2005, Teachers' pedagogical designs for technology-supported collective inquiry: A national case study. Computers \& Education, 45, 337-356.

LakKala, M., MuUkKonen, H. and Hakkarainen, K., 2005, Patterns of scaffolding in computer-mediated collaborative inquiry. Mentoring \& Tutoring, 13, 281-300.

Lamon, M., Secules, T., Petrosino, A., Hackett, R., Bransford, J. and Goldman, S., 1996, Schools for thought: Overview of the project and lessons learned from one of the sites. In Innovations in Learning: New Environments for Education, L. Schauble and R. Glaser (Eds.) (Mahwah: Erlbaum), pp. 243-288.

LAw, N., LeE, Y. and ChOw, A., 2002, Practice characteristics that lead to 21st century learning outcomes, Journal of Computer Assisted Learning, 18, 415-426.

Ligorio, B., TAlamo, A., and Pontecorvo, C., 2005, Building intersubjectivity at a distance during the collaborative writing of fairytales. Computers \& Education, $\mathbf{4 5}$, $357-374$.

LiM, C.P. and BARNES, S., 2002, "Those who can, teach" - The pivotal role of the teacher in the information and communication technologies (ICT) learning environment. Journal of Educational Media, 27, 19-40.

LipPonen, L., RAhiKainen, M., HAKKARAinen, K. and PAlonen, T., 2002, Effective participation and discourse through a computer network: Investigating elementary 
students' computer-supported interaction. Journal of Educational Computing Research, 27, 353-382.

MINISTRY OF EDUCATION, 1999, Education, Training and Research in the Information Society. A National Strategy for 2000-2004. Available online at: http://www.minedu.fi/julkaisut/information/englishU/welcome.html (accessed 4 November 2005).

MuukKonen, H., LakKala, M. and Hakkarainen, K., 2005, Technology-mediation and tutoring: How do they shape progressive inquiry discourse? The Journal of the Learning Sciences, 14, 527-565.

PAAVOLA, S., LiPPONEN, L., and HAKKARAINEN, K., 2002, Epistemological foundations for CSCL: A comparison of three models of innovative knowledge communities. In Computer Support for Collaborative Learning: Foundations for a CSCL community, G. Stahl (Ed.) (Hillsdale: Erlbaum), pp. 24-32.

PreECE, J., 2000, Online communities. Designing Usability, Supporting Sociability (West Sussex: John Wiley \& Sons).

PuntambeKar, S. and Kolodner, J.L., 2005, Toward implementing distributed scaffolding: Helping students learn science from design. Journal of Research in Science Teaching, 185-217.

Roschelle, J., Pea, R., Hoadley, C., Gordin, D. and Means, B., 2000, Changing how and what children learn in school with computer-based technologies. The Future of Children, 10, 76-101.

SAlOMON, G., 2002, Technology and pedagogy: Why don't we see the promised revolution? Educational Technology, 42, 71-75. 
SAlOVAARA, H. and JÄRVELÄ, S., 2003, Students' strategic actions in computer-supported collaborative learning. Learning Environments Research, 6, 267-284.

SCARDAMALIA, M., 2002, Collective cognitive responsibility for the advancement of knowledge. In Liberal Education in the Knowledge Society, B. Smith (Ed) (Chicago: Open Court), pp. 223-244.

SCARDAmAliA, M. and BerEiter, C., 1999, Schools as knowledge-building organizations. In Developmental Health and the Wealth of Nations: Social, Biological, and Educational Dynamics, D.P. Keating and C. Hertzman (Eds.) (New York: Guilford), pp. 274-289.

SCHRIRE, S., 2004, Interaction and cognition in asynchronous computer conferencing. Instructional Science, 32, 475-502.

SCHULER, D., 1996, New Community Networks. Wired for Change (New York: ACM Press \& Addison-Wesley Publishing Company).

ScOTT, J., 1991, Social Network Analysis: A Handbook (London: SAGE Publications).

Sinko, M. and LeHTinen, E., 1999, The Challenges of ICT in Finnish Education (Juva: Atena Kustannus).

SMEETS, E. and MooIJ, T., 2001, Pupil-centred learning, ICT, and teacher behaviour: observations in educational practice. British Journal of Educational Technology, 32, $403-417$.

SuTHERS, D.D. and HundHAusEn, C.D., 2003, An experimental study of the effects of representational guidance on collaborative learning processes. The Journal of the Learning Sciences, 12, 183-218.

TABAK, I., 2004, Synergy: a complement to emerging patterns of distributed scaffolding. Journal of the Learning Sciences, 13, 305-335. 
VEERMANS, M. and JÄRVELÄ, S., 2004, Generalized achievement goals and situational coping in inquiry learning. Instructional Science, 32, 269-291.

Veermans, M., Lallimo, J., \& Hakkarainen, K., 2005, Patterns of guidance in inquiry learning. Journal of Interactive Learning Research, 16, 179-194.

WAtson-Manheim, M.B., ChudobA, K.M., Crowston, K., 2002, Discontinuities and continuities: A new way to understand virtual work. Information Technology \& People, 15, 191-209.

WEGERIF, R., 1998, The social dimension of asynchronous learning networks. Journal of Asynchronous Learning Networks, 2, 34-49.

WindSCHITL, M. and SAHL, K., 2002, Tracing teachers' use of technology in a laptop computer school: The interplay of teacher beliefs, social dynamics, and institutional culture. American Educational Research Journal, 39, 165-205. 